\title{
The Influence of Host Country's Environmental Regulation on Enterprises' Risk Preference of Multinational Investment
}

\author{
Cheng Peng and Hui Jiang * \\ School of International Finance and Trade, Sichuan International Studies University, Chongqing, China
}

At present, China is in an important period of promoting high-quality economic development. In order to promote enterprises to "go global" and realize high-quality foreign investment, China advocates enterprises to abide by the environmental protection laws and regulations of the host country and standardize their environmental protection behaviors in foreign investment cooperation. However, the impact of the host country's environmental regulation on Chinese enterprise's multinational investment risk preference has not been paid enough attention. This paper makes an empirical analysis on how the

OPEN ACCESS

Edited by:

Faik Bilgili,

Erciyes University, Turkey

Reviewed by:

Erhan Mugaloglu, Abdullah Gül University, Turkey

Vishal Dagar,

Amity University, India

*Correspondence:

Hui Jiang

1016610374@qq.com

Specialty section:

This article was submitted to

Environmental Economics and

Management,

a section of the journal

Frontiers in Environmental Science

Received: 14 February 2021

Accepted: 26 October 2021

Published: 09 December 2021

Citation:

Peng $C$ and Jiang H (2021) The Influence of Host Country's Environmental Regulation on Enterprises' Risk Preference of

Multinational Investment.

Front. Environ. Sci. 9:667633. doi: 10.3389/fenvs.2021.667633 host country's environmental regulation affects the enterprises' risk preference of multinational investment (MIRP) by using the samples of A-share listed companies in China from 2010 to 2018 and emphatically examines the moderating effects of enterprise's green technology innovation and social responsibility on the relationship between host country's environmental regulation and enterprises' MIRP. It is found that, on the whole, the environmental regulation of the host country will significantly promote the enterprises' MIRP. The green technology innovation will positively moderate the impact of the environmental regulation of host country on enterprises' MIRP, while the engagement of corporate social responsibility will inhibit this positive impact.

Keywords: environmental regulation, corporate social responsibility, risk preference, green technology innovation, multinational investment

\section{INTRODUCTION}

Environmental regulation is an important factor that regulates enterprise' behavior and affects their investment and management. Since the 18th National Congress of the Communist Party of China, China has attached great importance to environmental protection and made efforts in various aspects to improve the system and mechanism, promote the formation of enterprise' environment-friendly investment and management philosophy, speed up the construction of ecological civilization, and build Community of Shared Future for Mankind. In 2013, the Ministry of Commerce and the Ministry of Environmental Protection jointly issued the Environmental Protection Guide for Foreign Investment Cooperation and stressed the need to further standardize the environmental protection behavior of enterprise in foreign investment cooperation and promote enterprise to comply with the laws and regulations of the host country on environmental protection. Therefore, the environmental regulation of the host country has become a very important factor in the process of Chinese enterprise "going global." 
Obviously, the strengthening of environmental regulation in the host country can change investment behavior and mode of enterprise, improve the green production efficiency, and fulfill the social responsibilities of enterprise, and also effectively safeguard the ecological environment of the host country. However, too strict environmental regulation often make enterprises hardly cope. According to the theory of "Pollution Shelter," strict environmental regulation will increase the cost of foreign investment and weaken the competitiveness of enterprise in the host country market, thus enabling enterprise to actively adjust the investment strategies and transfer investable projects to countries or regions with relatively loose environmental regulation, so as to maximize profits. At the same time, strict environmental regulation will also reduce the possibility of corporate investment because of the promotion of market access threshold, thus forcing enterprise to transfer the investment destinations and enter countries or regions with loose environmental regulation. However, countries or regions with loose environmental regulation usually lag behind in governance concepts, economic development, and even social turmoil, which will lead to higher investment risks. That is to say, in order to avoid the harsh environmental regulation of the host country, enterprise choose countries or regions with loose environmental regulation to invest and usually face higher host country risks. The level of environmental regulation in the host country should play a vital role in choosing the risk level of multinational investment of enterprise. According to the data of the World Investment Report 2020 released by the United Nations Conference on Trade and Development, the proportion of multinational investment flowing into developing economies increased from $36 \%$ in 2016 to $44.5 \%$ in 2019 , and the multinational investment of Chinese enterprises also showed the characteristics of being inclined to high-risk countries. Will the host country's environmental regulation affect the risk choice of enterprise's multinational investment? Does the high-risk characteristics of multinational investment originate from the influence of the host country's environmental regulation? These questions are related to the optimization of enterprise's multinational investment decisions and also contribute to the optimization of environmental regulation in host country, so they are problems worthy of our indepth study.

However, at present, the research on the impact of environmental regulation on enterprise's multinational investment mainly focuses on the test of "Pollution Shelter Hypothesis" and "Porter Hypothesis," which try to explore the impact of environmental regulation on enterprises' productivity and industrial transfer. Those factors influencing on the national risk preference of enterprises' multinational investment only focus on internal factors, such as financing constraints, experience accumulation, senior management cognition, and social class (Yu Guansheng, 2017; Yu Sheng et al., 2018; Shu and Du, 2020; Du et al., 2020), and external factors, such as cultural distance, bilateral relations, policy uncertainty, agglomeration economy, and legal spillover (Kang and Jiang, 2012; Quer et al., 2012; Belderbos et al., 2011; Li and Yao, 2010; Delios, 2001; John and Lawton, 2018). Presently, there is no research on the relationship between the host country's environmental regulation and the risk preference of enterprises' multinational investment.

In order to explore the relationship between host country's environmental regulation and enterprises' risk preference for multinational investment (MIRP), this paper takes A-share listed companies from 2010 to 2018 as sample, analyzes the influence of host country's environmental regulation on enterprise's MIRP, and tests the moderating effect of enterprise's green technology innovation and social responsibility. The possible contributions of this paper are as follows: first, constructing the risk preference index of enterprises' multinational investment and exploring the influence of host country's environmental regulation on it, which not only expands the research of enterprises' risk preference but also broadens the research horizon of environmental regulation. Second, from the perspectives of green technology innovation and social responsibility, this paper studies the mechanism of the host country's environmental regulation on the enterprises' MIRP and deepens the relevant theory of the formation mechanism of enterprises' MIRP. Third, under different industries, property rights, life cycle stages, and host country types, the influence of the host country's environmental regulation on enterprises' MIRP and the moderating role of green technology innovation and social responsibility are discussed, which provide empirical evidence for investment decision optimization of different types of enterprises and government policy making. The conclusion of this paper is helpful to deepen the understanding of the basic characteristics and patterns of Chinese enterprises' multinational investment and provides a useful reference for the improvement of relevant national policies and international economic exchanges.

\section{THEORY AND RESEARCH HYPOTHESES}

The research on environmental regulation and enterprise behavior originates from people's understanding of the relationship between environment and economic development. Among them, some scholars believe that economic development will have an impact on environmental quality and that economic, financial, and trade development will lead to environmental degradation (Khan et al., 2021; Sharma et al., 2021a; Islam et al., 2021; Sharma et al., 2021b; Shahbaz et al., 2020). Other scholars believe that environmental changes will in turn play an important role in economic factors such as production technology, consumption structure, and economic progress (Dagar et al., 2021; Sinha and Shahbaz, 2018; Zakari et al., 2021; Rehman et al., 2021). These studies have laid an important foundation for the construction of environmental regulation and the optimization of enterprises' multinational investment under environmental regulation, and inspired the relevant research on enterprises' multinational investment risk preference under environmental regulation. Specifically, the research in this area can be divided into the following three aspects. 


\section{Host Country' Environmental Regulation and Enterprises' MIRP}

Environmental regulation is a way for the government or organization to restrain economic subjects to take environmental responsibility by means of laws and administrative orders, a means to solve the "market failure" of environmental problems, and an important measure to realize industrial structure adjustment (Tong et al., 2016). For this reason, the host country's environmental regulation will play a key role in enterprises' foreign direct investment, which is mainly manifested in the industrial transfer effect and the industrial international competitiveness effect.

First is the effect of industrial transfer. This effect originates from the "Pollution Shelter Hypothesis" proposed by Copeland and Taylor (1995), which mainly means that the strengthening of environmental regulation in the home country leads to the increase in environmental compliance costs of domestic pollution-related industries. Under the new environmental regulation, enterprises have to change the way of resource input and reallocate some resources used for production to pollution control, thus reducing output and increasing costs. In order to escape from harsh environmental regulation, enterprises tend to choose countries with relatively loose environmental regulation for production, so as to reduce the cost of environmental compliance. Therefore, the flow of multinational investment of enterprises will change due to the differences in environmental regulations between countries, which has been widely verified by scholars (chung, 2014; Tang, 2015; Cai et al., 2016; Zheng and Shi, 2017). Second is the effect of industrial international competitiveness. According to this theory, the strengthening of domestic environmental regulation has changed the original production constraints of polluting industries. If the intensity of environmental regulation in other countries remains unchanged, the international comparative advantage of domestic polluting industries will weaken or disappear compared with other countries. Therefore, the decline in international competitiveness of industries will make enterprises transfer from countries with enhanced environmental regulation to other countries (Cole et al., 2005; Fu and Li, 2010).

Li, (2020) holds that, generally speaking, the more developed the economy, the more stable the politics, and the more perfect the financial system, the higher the level of environmental regulation will be. Otherwise, the lower. In order to develop local economy, backward countries or regions often choose lower environmental regulation level to attract investment from foreign enterprises. However, these countries usually have higher investment risks because of imperfect systems or low development level. Therefore, in order to avoid the cost of environmental regulation, enterprises will enhance their willingness to take risks and increase their investment in countries with weak environmental regulation but relatively high overall risks.

Based on the above analysis, hypothesis $\mathrm{H} 1$ can be put forward: the host country' environmental regulation will promote the enterprises' MIRP.

\section{Host Country's Environmental Regulation, Green Technology Innovation, and Enterprises' MIRP}

The above analysis shows that the host country's environmental regulation will affect the enterprises' MIRP. However, as we all know, the risk-taking or risk preference of an enterprise is usually related to its own strength or scientific and technological level. The better the scientific and technological level, the higher the overall efficiency of the enterprise, and the stronger its risk-taking ability. Therefore, the innovation level of enterprises, including green technology innovation, will play a key role in the enterprises' MIRP. That is to say, enterprises can usually influence their multinational investment decision-making and risk preference by strengthening green technology innovation and play a moderating role in the influence of the host country' environmental regulation on enterprises' MIRP.

Specifically, green technology innovation will play an important role in enterprises' multinational investment decisions by improving their economic performance and environmental performance. From the perspective of economic performance, green technology innovation cannot only improve efficiency, restrain waste of resources by minimizing costs, effectively improve social performance and financial performance of enterprises, and enhance enterprise value (Weng et al., 2015) but also help enterprises to expand production scale and increase market share, and even increase profits through green technology patent transfer (Wang et al., 2021). Therefore, the green technology patents produced by technical innovation activities can provide enterprises with sustainable competitive advantages and lay a foundation for their development (Dangelico and Pontrandolfo, 2013) and thus improve their risk-taking ability and risk preference. From the perspective of environmental performance, the existing research shows that there is a significant positive correlation between enterprise green technology innovation and environmental performance (Kraus et al., 2020). Through green technology innovation, the benefits of enterprises in pollution control, natural resources protection, and ecological restoration can be enhanced (Wang et al., 2021), thus enhancing the environmental performance and comprehensive competitiveness of enterprises and realizing the sustainable development of enterprises. Therefore, enterprises can improve their antirisk ability through green technology innovation, thus affecting their risk preference of multinational investment, and finally effectively moderating the influence of the host country's environmental regulation on enterprises' MIRP.

Based on the above analysis, hypothesis $\mathrm{H} 2$ can be put forward: green technology innovation positively moderates the impact of the host country's environmental regulation on enterprises' MIRP.

\section{Host Country's Environmental Regulation, Social Responsibility, and Enterprises' MIRP}

Corporate social responsibility is a moral requirement of enterprises, and it is an additional contribution made by enterprises to social welfare (Carroll and Shabana, 2010; Lin 


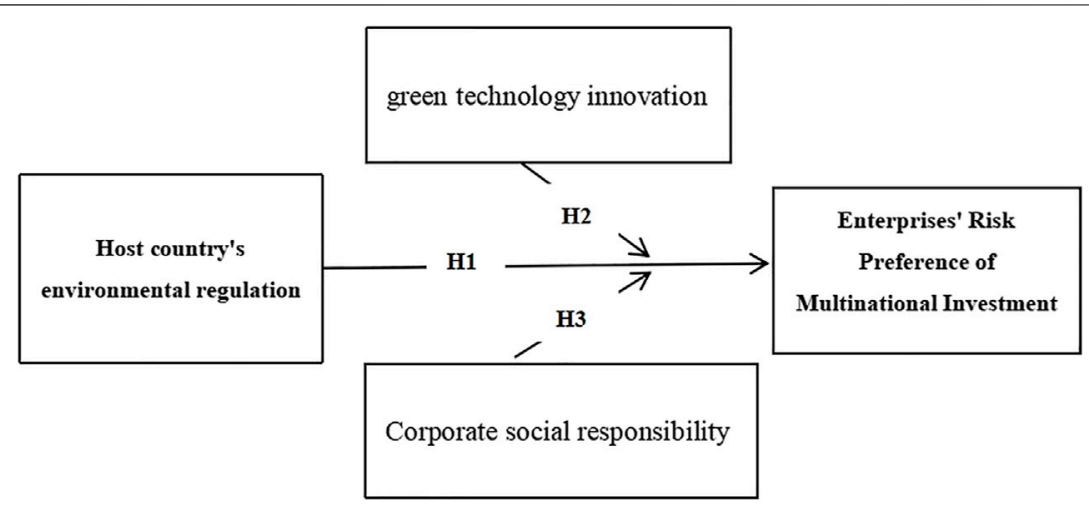

FIGURE 1 | Graphical representation of the research framework.

Hi and Muller, 2013). The undertaking of social responsibility usually requires enterprises to break through the pure cost-benefit framework and fully respond to the demands of external stakeholders in the production and operation decisionmaking, which will play an important role in the investment decision-making of enterprises and will also play a moderating role in the impact of the host country's environmental regulation on enterprises' MIRP.

To engage in social responsibility, enterprises should fully take care of the concerns of external stakeholders and try to realize the overall interests of society and hence changing the production and operation behavior characterized by value maximizing. Generally speaking, enterprises that actively fulfill their social responsibilities will pay more attention to the long-term interest and reduce short-term opportunistic behaviors. Therefore, such enterprises will have fewer information asymmetry problems and principal-agent problems (Ghoul et al., 2011), which will lead to lower financing costs. At the same time, because of the fulfillment of social responsibility, enterprises will have a better social image and corporate reputation, which will win the favor of financial institutions and regulatory authorities, thus obtaining more financing support (Lin et al., 2015; Zhao and Xiao, 2019). Therefore, the commitment of social responsibility can improve the borrowing capacity, reduce the financing cost of enterprises, and thus offset the increased costs of enterprises due to strict environmental regulation, so the motivation of enterprises to invest in countries with strong environmental regulation but low overall risks will be strengthened. It can be judged from this that, although enterprises tend to invest in countries with weak environmental regulation when the host country's environmental regulation is stricter, this tendency will decrease with the increase in corporate social responsibility (Zhao et al., 2015). Enterprises that actively fulfill their social responsibilities often adopt stricter environmental standards independently, and will still be willing to stay in countries with strict environmental regulation, and their MIRP will be restrained to some extent.
Based on the above analysis, the hypothesis $\mathrm{H} 3$ is put forward: corporate social responsibility negatively moderates the impact of host country's environmental regulation on enterprises' MIRP.

The research framework that guides the study is represented in Figure 1.

\section{RESEARCH DESIGN}

\section{Sample and Data Sources}

In this paper, we selected enterprises with multinational investment listed in Shanghai and Shenzhen stock markets from 2010 to 2018 as the research samples and finally obtained 8,032 valid observation samples after excluding ST and ${ }^{*} \mathrm{ST}$ enterprises and those taking tax-free islands and tax havens as multinational investment destinations. The relevant data of multinational investment events of enterprises are collected and collated through the annual reports of multinational corporations, and other data of enterprises come from the economic and financial database of CASMER. The environmental performance index of the host country comes from the official website of Socioeconomic Data and Applications Center (SEDAC). The risk data of the host countries come from the international risk index (ICRG), and other data of the host countries are selected from the official website of the World Bank.

\section{Definition of Variables \\ Dependent Variable}

Dependent variable is enterprises' risk preference of multinational investment (MIRP), which is calculated by the following steps:

1 Constructing the national risk index of the host country

The national risk of the host country is measured by the International Risk Index (ICRG), which is published by the American Political Risk Service Group (PRS). This index is composed by political risk, economic risk, and financial risks of more than 100 countries. The higher the score, the lower the risk. Considering the suitability of these indicators and drawing lessons from Yuan and Chen (2018), this paper uses 14 indicators 
TABLE 1 | National risk index system of host country.

\begin{tabular}{|c|c|c|c|}
\hline Risk categories & Indicators & Score & Meaning \\
\hline \multirow[t]{4}{*}{ Political Risk (PR) } & Government Stability $\left(X_{1}\right)$ & $0-12$ & The higher the score, the lower the risk \\
\hline & Investment Profile $\left(X_{2}\right)$ & $0-12$ & \\
\hline & Bureaucracy Quality $\left(X_{3}\right)$ & $0-6$ & \\
\hline & Law \& Order $\left(X_{4}\right)$ & $0-4$ & \\
\hline \multirow[t]{5}{*}{ Economic Risk (ER) } & Risk for Per Capita GDP $\left(X_{5}\right)$ & $0-5$ & \\
\hline & Risk for GDP Growth $\left(X_{6}\right)$ & $0-10$ & \\
\hline & Risk for Inflation $\left(X_{7}\right)$ & $0-10$ & \\
\hline & Risk for Budget Balance $\left(X_{8}\right)$ & $0-10$ & \\
\hline & Risk for Current Account as \% of GDP $\left(X_{9}\right)$ & $0-15$ & \\
\hline \multirow[t]{5}{*}{ Financial Risk (FR) } & Risk for Foreign Debt $\left(X_{10}\right)$ & $0-10$ & \\
\hline & Risk for Debt Service $\left(X_{11}\right)$ & $0-10$ & \\
\hline & Risk for Current Account as \% of XGS $\left(X_{12}\right)$ & $0-15$ & \\
\hline & Risk for International Liquidity $\left(X_{13}\right)$ & $0-5$ & \\
\hline & Risk for Exchange Rate Stability $\left(X_{14}\right)$ & $0-10$ & \\
\hline
\end{tabular}

TABLE 2 | KMO and Bartlett's test results.

\begin{tabular}{llc}
\hline Kaiser-Meyer-OIkin measure of sampling adequacy & $\mathbf{0 . 7 2 4}$ \\
\hline Bartlett's Test of Sphericity & Approx.Chi-Square & $81,344.525$ \\
& Df & 91 \\
Sig & 0.000
\end{tabular}

to construct the national risk index of the host country, as shown in Table 1:

2 Calculating the national risk index of the host country (CR) by principal component analysis

(i) Standardized data processing and applicability test

In this paper, using SPSS 23.0 software, the commonly used variance standardization method is used to standardize the driving factor value and transform it into a dimensionless value. The standardization formula is shown in Eqs 1 and 2:

$$
x_{i}^{\prime}=\frac{\mathrm{x}_{\mathrm{i}}-\mathrm{x}}{\sigma}
$$

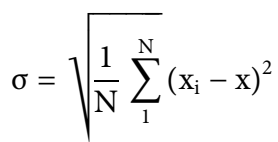

Among them, $x_{i}^{\prime}$ is the standardized value of the factor, $x_{i}$ is the original value of the factor, $\mathrm{x}$ is the average of factors, and $\sigma$ is the standard deviation of factors. After obtaining the new data, PCA was carried out. First, KMO test and Bartlett sphere test are used to test the applicability of PCA. Practice has proved that the stronger the correlation between variables, the better the result of PCA. The value of KMO statistics is between 0 and 1 . It is calculated whether the square of Pearson correlation coefficient between variables is much larger than the sum of squares of partial correlation coefficients. When $\mathrm{KMO}$ is close to 1 , it means that the difference between the two variables is insufficient, indicating that there is a strong correlation between variables, so the PCA of the original variables can get ideal results. According to the results, KMO value is 0.724 , which indicates that there is a strong correlation among these 14 variables, which is suitable for PCA. Bartlett sphere test is used to test whether the variables are independent. The original assumption is that the correlation coefficient matrix is identity matrix. If the

\begin{tabular}{|c|c|c|c|c|c|c|c|c|c|}
\hline \multirow[t]{2}{*}{ Component } & \multicolumn{3}{|c|}{ Initial eigenvalue } & \multicolumn{3}{|c|}{ Extracting sum of squares loading } & \multicolumn{3}{|c|}{ Rotation sums of squared loadings } \\
\hline & Total & $\begin{array}{c}\% \text { of } \\
\text { variance }\end{array}$ & Cumulative \% & Total & $\begin{array}{c}\% \text { of } \\
\text { variance }\end{array}$ & Cumulative \% & Total & $\begin{array}{c}\% \text { of } \\
\text { variance }\end{array}$ & Cumulative \% \\
\hline 1 & 4.743 & 33.879 & 33.879 & 4.743 & 33.879 & 33.879 & 4.698 & 33.560 & 33.560 \\
\hline 2 & 2.867 & 20.479 & 54.358 & 2.867 & 20.479 & 54.358 & 2.824 & 20.174 & 53.734 \\
\hline 3 & 1.314 & 9.384 & 63.742 & 1.314 & 9.384 & 63.742 & 1.270 & 9.071 & 62.806 \\
\hline 4 & 1.085 & 7.750 & 71.491 & 1.085 & 7.750 & 71.491 & 1.216 & 8.686 & 71.491 \\
\hline 5 & 0.992 & 7.083 & 78.574 & & & & & & \\
\hline 6 & 0.868 & 6.203 & 84.777 & & & & & & \\
\hline 7 & 0.642 & 4.588 & 89.365 & & & & & & \\
\hline 8 & 0.435 & 3.108 & 92.473 & & & & & & \\
\hline 9 & 0.358 & 2.554 & 95.027 & & & & & & \\
\hline 10 & 0.268 & 1.911 & 96.938 & & & & & & \\
\hline 11 & 0.178 & 1.272 & 98.210 & & & & & & \\
\hline 12 & 0.122 & 0.870 & 99.080 & & & & & & \\
\hline 13 & 0.072 & 0.511 & 99.591 & & & & & & \\
\hline 14 & 0.057 & 0.409 & 100.000 & & & & & & \\
\hline
\end{tabular}

TABLE 3 | Total variance explained. 
TABLE 4 | Component matrix and rotation component matrix.

\begin{tabular}{|c|c|c|c|c|c|c|c|c|}
\hline & \multicolumn{4}{|c|}{ Component matrix } & \multicolumn{4}{|c|}{ Rotation component matrix } \\
\hline & \multicolumn{4}{|c|}{ Component } & \multicolumn{4}{|c|}{ Component } \\
\hline & $\mathbf{F}_{1}$ & $\mathbf{F}_{2}$ & $\mathbf{F}_{3}$ & $\mathbf{F}_{4}$ & $\mathbf{F}_{1}$ & $\mathbf{F}_{2}$ & $\mathbf{F}_{3}$ & $\mathbf{F}_{4}$ \\
\hline$X_{1}$ & 0.034 & 0.169 & 0.397 & -0.791 & 0.11 & 0.032 & -0.102 & 0.888 \\
\hline$x_{2}$ & 0.813 & 0.014 & 0.101 & 0.064 & 0.816 & 0.001 & 0.063 & -0.071 \\
\hline$x_{3}$ & 0.898 & -0.056 & 0.179 & -0.125 & 0.914 & -0.102 & 0.026 & 0.109 \\
\hline$X_{4}$ & 0.823 & 0.14 & 0.111 & 0.064 & 0.831 & 0.125 & 0.063 & -0.049 \\
\hline$X_{5}$ & 0.159 & 0.513 & 0.212 & 0.14 & 0.193 & 0.518 & 0.211 & 0.055 \\
\hline$X_{6}$ & 0.002 & 0.931 & -0.065 & 0.019 & 0.026 & 0.923 & -0.101 & 0.083 \\
\hline $\mathrm{X}_{7}$ & 0.007 & 0.938 & -0.093 & 0.039 & 0.028 & 0.934 & -0.116 & 0.052 \\
\hline$X_{8}$ & 0.281 & 0.162 & 0.481 & 0.465 & 0.318 & 0.211 & 0.624 & -0.133 \\
\hline$X_{9}$ & -0.414 & 0.344 & 0.486 & -0.283 & -0.339 & 0.292 & 0.265 & 0.58 \\
\hline$X_{10}$ & -0.363 & -0.295 & 0.715 & 0.279 & -0.305 & -0.259 & 0.792 & 0.139 \\
\hline$X_{11}$ & 0.78 & 0.319 & 0.023 & 0.102 & 0.785 & 0.311 & 0.002 & -0.098 \\
\hline $\mathrm{X}_{12}$ & -0.663 & 0.38 & -0.169 & 0.089 & -0.667 & 0.41 & -0.073 & -0.049 \\
\hline$X_{13}$ & -0.523 & 0.561 & 0.017 & 0.077 & -0.501 & 0.579 & 0.057 & 0.073 \\
\hline$X_{14}$ & 0.931 & 0.121 & -0.189 & -0.124 & 0.913 & 0.082 & -0.295 & -0.065 \\
\hline
\end{tabular}

$p$-value of the test result is $<0.05$, the original hypothesis is rejected, and PCA is suitable. After examination, Bartlett test $p$-value is 0.000 , so the original hypothesis is rejected, and it is considered that there is significant correlation between variables, and the data are suitable for PCA. The results are shown in Table 2.

\section{(ii) Extracting principal component factors}

PCA was carried out on 14 index data, and the initial eigenvalue, variance contribution, and cumulative contribution of variance of each variable were calculated in Table 3. Four principal components with eigenvalues $>1$ are selected, and the cumulative variance contribution rate is $71.491 \%$, which can reflect the information of most indicators. Therefore, components 1-4 can be used as principal components of the original data set instead of the original 14 indicators; that is, the original 14 indicators can be summarized into four principal components representing the comprehensive risk index of the host country. In order to make the coefficients in the matrix of principal component load more significant, the initial load matrix is rotated so that the relationship between principal components and original variables is redistributed, and the absolute values of correlation coefficients are polarized to the $(0,1)$ interval, which makes it easier to explain. It can be seen that the variance of the four principal components after rotation accounts for $33.560 \%, 20.174 \%, 9.071 \%$, and $8.686 \%$ of the variance of all principal components, respectively.

(iii) Calculating the principal component score and the national risk comprehensive score of each host country

According to Table 4 the linear combination of $\mathrm{F}_{1}, \mathrm{~F}_{2}, \mathrm{~F}_{3}$, and $\mathrm{F}_{4}$ is obtained by using the four principal component coefficients in the rotated component matrix, and the national risk index (CR) of each host country in 2010-2018 is calculated according to the principal component scores calculated by Eqs 3-6 and weighted by the ratio of variance contribution of each principal component to total variance contribution of four factors. Due to space limitation, it only lists some results of 2017 in Table 5:

$$
\begin{aligned}
\mathrm{F}_{1}= & 0.051 \mathrm{X}_{1}+0.375 \mathrm{X}_{2}+0.420 \mathrm{X}_{3}+0.382 \mathrm{X}_{4}+0.089 \mathrm{X}_{5}+0.012 \mathrm{X}_{6} \\
& +0.013 \mathrm{X}_{7}+0.146 \mathrm{X}_{8}-0.156 \mathrm{X}_{9}-0.140 \mathrm{X}_{10}+0.360 \mathrm{X}_{11}-0.306 \mathrm{X}_{12} \\
& -0.230 \mathrm{X}_{13}+0.419 \mathrm{X}_{14}
\end{aligned}
$$

$$
\begin{aligned}
\mathrm{F}_{2}= & 0.019 \mathrm{X}_{1}+0.001 \mathrm{X}_{2}-0.060 \mathrm{X}_{3}+0.074 \mathrm{X}_{4}+0.306 \mathrm{X}_{5}+0.545 \mathrm{X}_{6} \\
& +0.552 \mathrm{X}_{7}+0.125 \mathrm{X}_{8}+0.172 \mathrm{X}_{9}-0.153 \mathrm{X}_{10}+0.184 \mathrm{X}_{11}+0.242 \mathrm{X}_{12} \\
& +0.342 \mathrm{X}_{13}+0.048 \mathrm{X}_{14}
\end{aligned}
$$

$$
\begin{aligned}
\mathrm{F}_{3}= & -0.089 \mathrm{X}_{1}+0.001 \mathrm{X}_{2}-0.060 \mathrm{X}_{3}+0.074 \mathrm{X}_{4} \\
& +0.306 \mathrm{X}_{5}+0.545 \mathrm{X}_{6}+0.552 \mathrm{X}_{7}+0.125 \mathrm{X}_{8}+0.172 \mathrm{X}_{9}-0.153 \mathrm{X}_{10} \\
& +0.184 \mathrm{X}_{11}+0.242 \mathrm{X}_{12}+0.342 \mathrm{X}_{13}+0.048 \mathrm{X}_{14}
\end{aligned}
$$

$$
\begin{aligned}
\mathrm{F}_{4}= & 0.853 \mathrm{X}_{1}-0.068 \mathrm{X}_{2}+0.105 \mathrm{X}_{3}-0.047 \mathrm{X}_{4}+0.053 \mathrm{X}_{5}+0.080 \mathrm{X}_{6} \\
& +0.050 \mathrm{X}_{7}-0.128 \mathrm{X}_{8}+0.557 \mathrm{X}_{9}+0.133 \mathrm{X}_{10}-0.094 \mathrm{X}_{11}-0.047 \mathrm{X}_{12} \\
& +0.070 \mathrm{X}_{13}-0.062 \mathrm{X}_{14}
\end{aligned}
$$

Combined with the rotated component matrix, it can be seen that the principal component $F_{1}$ has a larger load value in Investment Profile $\left(\mathrm{X}_{2}\right)$, Bureaucracy Quality $\left(\mathrm{X}_{3}\right)$, Law \& Order $\left(\mathrm{X}_{4}\right)$, Risk for Exchange Rate Stability $\left(\mathrm{X}_{14}\right)$, etc. F2 has a large load value on the indicators such as Risk for GDP Growth $\left(\mathrm{X}_{6}\right)$, Risk for Inflation $\left(\mathrm{X}_{7}\right)$, and Risk for International Liquidity $\left(\mathrm{X}_{13}\right) . \mathrm{F}_{3}$ has a large load value on Risk for Budget Balance $\left(\mathrm{X}_{8}\right)$, Risk for Budget Balance $\left(\mathrm{X}_{10}\right)$, etc. $\mathrm{F}_{4}$ has a large load value on Government Stability $\left(\mathrm{X}_{1}\right)$, Risk for Current Account as \% of GDP $\left(\mathrm{X}_{9}\right)$ and other indicators.

3 Through Eq. 7, all the national risks of the host country involved in the multinational investment of enterprises are integrated from the horizontal value level to measure the degree of enterprises' MIRP.

$$
M I R P_{i, t}=w_{i, j, t} C R_{j, t}
$$

Among them, $\operatorname{MIRP}_{i, t}$ is the risk preference of multinational investment of company $i$ in year $t$ and is the weighted average of the national risks of all host countries involved in company $i$. This 
TABLE 5 | Some comprehensive score results of national risk in 2017.

\begin{tabular}{lccccc}
\hline Country & $\mathbf{F}_{\mathbf{1}}$ & $\mathbf{F}_{\mathbf{2}}$ & $\mathbf{F}_{\mathbf{3}}$ & $\mathbf{F}_{\mathbf{4}}$ & $\mathbf{C R}$ \\
\hline Thailand & 10.439 & 26.017 & 8.893 & 3.303 & 6.503 \\
Korea, South & 11.905 & 25.663 & 8.422 & 3.144 & 6.251 \\
United Kingdom & 12.112 & 25.613 & 8.356 & 3.121 & 6.216 \\
United States & 11.715 & 25.708 & 8.483 & 3.165 & 6.284 \\
Japan & 11.043 & 25.871 & 8.699 & 3.238 & 6.399 \\
Poland & 12.112 & 25.613 & 8.356 & 3.121 & 6.216 \\
Denmark & 11.698 & 25.713 & 8.489 & 3.166 & 6.287 \\
Germany & 12.112 & 25.613 & 8.356 & 3.121 & 6.216 \\
Australia & 10.801 & 25.929 & 8.777 & 3.264 & 6.441 \\
Netherlands & 9.766 & 26.179 & 9.109 & 3.376 & 6.618 \\
Sweden & 10.249 & 26.063 & 8.954 & 3.324 & 6.535 \\
South Africa & 11.491 & 25.763 & 8.555 & 3.189 & 6.322 \\
Pakistan & 10.991 & 25.883 & 8.716 & 3.243 & 6.408 \\
Bangladesh & 10.042 & 26.113 & 9.021 & 3.346 & 6.571 \\
Iran & 11.491 & 25.763 & 8.555 & 3.189 & 6.322 \\
Mexico & 10.249 & 26.063 & 8.954 & 3.324 & 6.535 \\
Brazil & 10.042 & 26.113 & 9.021 & 3.346 & 6.571 \\
Russia & 10.335 & 26.042 & 8.926 & 3.315 & 6.521 \\
Vietnam & 10.870 & 25.913 & 8.755 & 3.256 & 6.429 \\
Italy & 9.628 & 26.213 & 9.154 & 3.391 & 6.642 \\
France & 7.144 & 26.813 & 9.952 & 3.661 & 7.068 \\
& & & & &
\end{tabular}

paper refers to Mihov and Naranjo (2019): divide the number of subsidiaries of company $i$ in host country $j$ by the total number of overseas subsidiaries owned by company $i$ in year $t$ as weight $w_{i, j}$, t. Subsequently, if the results of $M I R P_{i, t}$ are higher than or equal to the median per year, they would be assigned as 0 , indicating that the enterprises' MIRP is low. Similarly, the results lower than the median per year would be assigned as 1 , indicating that the enterprises' MIRP is high.

\section{Independent Variable}

\section{Environmental Regulation Intensity (RPI)}

Yale University and Columbia University jointly released the environmental performance index EPI. The EPI index scores according to the gap between the performance of each country in each index and the established target. The higher the score, the stronger the environmental regulation level. Therefore, it provides a quantitative analysis basis for economists to analyze the environmental regulation policies of all countries. Based on the index of EPI, referring to Wu and Zheng (2020), this paper adopts environmental regulation intensity (RPI) to measure the environmental regulation of each country. It is calculated as follows:

$$
R P I=\left(E P I_{\text {other }}-E P I_{\text {China }}\right) / E P I_{\text {China }}
$$

Among them, $E P I_{\text {China }}$ is the environmental performance index of China, and $E P I_{\text {other }}$ is that of other countries or regions. A positive RPI indicates that the host country's relative environmental regulation intensity is higher, while China's relative environmental regulation intensity is lower and vice versa. Figure 2 shows the changes and trends of environmental regulation intensity of host countries from 2010 to 2018 .

\section{Moderating Variables}

\section{Green Technology Innovation}

In this paper, the number of green patent applications (Gpatents) is used as an index to measure the enterprise's green technology innovation ability. The raw data of the number of green patent applications of enterprises is based on the practice of Wang Xiaoqi et al. (2020). Python software is used to search and crawl on the website of the State Intellectual Property Office, with the names of enterprises (including former names) and IPC classification numbers listed in IPC Green Inventory as keywords. In this paper, the number of patents (i.e., the number of green patent applications) that are consistent with the IPC classification numbers included in the List among patents applied by listed companies is collected and counted year by year.

\section{Corporate Social Responsibility}

In this paper, the social responsibility rating index (CSR) of listed companies published by the website of Hexun is used to measure the level of corporate social responsibility. This evaluation system investigates from five aspects: shareholders' responsibility, employees' responsibility, suppliers', customers' and consumers' rights and interests' responsibility, environmental responsibility, and social responsibility.

\section{Control Variables}

In this paper, the control variables at the host country level and the enterprise level are selected to control the influence of the host country's environmental regulation on the enterprises' MIRP from these two aspects.

See Table 6 for the definition of variables and measurement indexes used in this paper.

\section{Model Construction}

In order to verify whether the host country's environmental regulation promotes or inhibits the enterprises' MIRP, the following fixed-effects model 1 was constructed. In accordance with the moderating effect analysis, Model 2 and Model 3 were further constructed to test whether green technology innovation (Gpatents) and corporate social responsibility (CSR) affect the role of host country's environmental regulation on enterprises' MIRP.

Model 1:

$$
M I R P_{i, t}=\alpha+\beta_{11} R P I_{i, t}+\beta_{12} \sum \text { Controls }_{i, t}+\varepsilon_{1}
$$

Model 2:

$$
\begin{aligned}
\operatorname{MIRP}_{i, t}=\alpha & +\beta_{21} R P I_{i, t}+\beta_{22} R P I_{i, t} \times \text { Gpatents }_{i, t} \\
& +\beta_{23} \sum \text { Controls }_{i, t}+\varepsilon_{2}
\end{aligned}
$$

Model 3:

$$
\begin{aligned}
\operatorname{MIRP}_{i, t}=\alpha & +\beta_{31} R P I_{i, t}+\beta_{32} R P I_{i, t} \times \operatorname{CSR}_{i, t} \\
& +\beta_{33} \sum \text { Controls }_{i, t}+\varepsilon_{3}
\end{aligned}
$$

Among them, $M I R P_{i, t}$ is the enterprise' risk preference of multinational investment, $R P I$ is environmental regulation intensity, $\beta_{i}$ is the regression coefficient, $\varepsilon_{i}$ is the residual, and ccontrols is the sum of control variables. If $\beta_{11}$ is positive in the regression results, it means that environmental regulation is positively correlated with the enterprises' MIRP; otherwise, it is negatively correlated. If $\beta_{22}$ is significantly positive, it means that enterprises' green technology innovation plays a positive moderating 


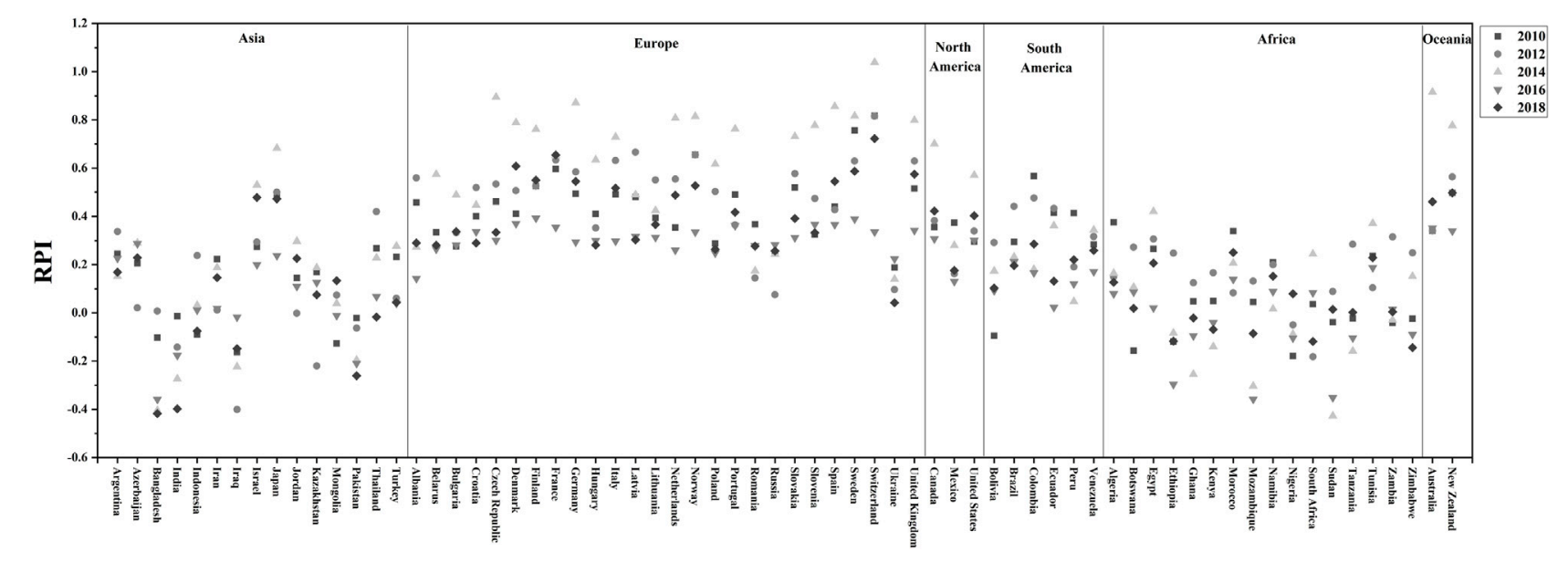

FIGURE 2 | Environmental regulation differences in host countries from 2010 to 2018.

TABLE 6 | Definition of variables and measurement indexes.

Variable types

Variable

Dependent

variable

Independent

variable

Moderating

variables

Control variables
Enterprises' risk preference of multinational investment (MIRP)

Environmental regulation intensity (RPI)

Green technology Innovation (Gpatents) Corporate social responsibility (CSR)

The per capita GDP of the host country (LnGDPP)

Natural resource endowment of host country (RAW)

Human resource endowment of host country

(LnLAB)

Technology resource endowment of host country

(Lnpatent)

The enterprise' scale (LnSize)

Profit margin on corporate net assets (ROA)

Asset-liability ratio of enterprises (Lev)

The growth of the enterprise (Grows)

The capital-labor ratio of the enterprise (alab)

Enterprise age (CA)

The level of foreign capital utilization of enterprises (Share)

Whether there are foreign executives (Foreign)

Whether it's a state-owned enterprise (Cont)

Industry

Year

\section{Measurement}

The composite risk index of ICRG 14 indicators is calculated by principal component analysis and is obtained by weighted average of the number of subsidiaries

The difference in EPI index scores between host country and China and the ratio of EPI index in China

The number of green patent applications by enterprises in that year

HeXun corporate social responsibility report

The natural logarithm of the host country's per capita GDP

The host country's total natural resource rents are measured as a percentage of GDP

The natural logarithm of the total workforce population of the host country

The natural logarithm of the number of patent applications in the host country

The logarithm of the total assets of an enterprise

The ratio of after-tax net profit to total assets

The ratio of total assets to total liabilities

Business revenue growth rate

The ratio of net fixed assets to the number of employees

The number of years from the year of establishment to the year of study

The proportion of foreign shareholders in the shareholding structure

The presence of foreign executive assigned a value of 1 , otherwise assigned a value of 0

The state-owned enterprise assigned a value of 1 , otherwise assigned a value of 0

Control

Control role, and otherwise a negative moderating role; if $\beta_{32}$ is significantly positive, it means that corporate social responsibility plays a positive moderating role, and otherwise a negative moderating role.

\section{EMPIRICAL RESULTS}

\section{Descriptive Statistics and Correlation Analysis}

In this study, stata16 was used to make descriptive statistics and correlation analysis of the variables involved, and the analysis results are shown in Table 7. Descriptive statistical results show the mean and standard deviation of each variable.
Observational correlation analysis results show that there is a positive correlation between the host country's environmental regulation and the enterprises' MIRP. In addition, there is a significant correlation between the enterprises' MIRP and the relevant control variables, which further verifies the rationality and feasibility of the assumptions in this paper to a certain extent, but it should be further analyzed with regression test.

\section{Baseline Regression Analysis}

Model 1 tests the relationship between the host country's environmental regulation and enterprises' MIRP, and the regression results are shown in Table 8 . The regression 
TABLE 7 | Descriptive statistical results and correlation analysis.

\begin{tabular}{|c|c|c|c|c|c|c|c|}
\hline Variables & 1 & 2 & 3 & 4 & 5 & 6 & 7 \\
\hline MIRP & 1.000 & & & & & & \\
\hline $\mathrm{RPI}$ & $-0.239^{\star \star \star}$ & 1.000 & & & & & \\
\hline InGDPP & $-0.540^{\star * \star}$ & $0.464^{\star \star \star}$ & 1.000 & & & & \\
\hline RAW & $0.260^{\star \star \star}$ & $-0.175^{\star \star \star}$ & $-0.385^{\star \star \star}$ & 1.000 & & & \\
\hline $\ln \llcorner A B$ & $0.112^{\star \star \star}$ & $-0.200^{\star \star \star}$ & $-0.115^{\star \star \star}$ & $-0.247^{\star \star \star \star}$ & 1.000 & & \\
\hline Growth & 0.014 & -0.002 & -0.011 & -0.004 & 0.000 & 1.000 & \\
\hline Lev & $0.156^{\star \star \star}$ & $-0.049^{\star \star \star}$ & $-0.095^{\star \star \star}$ & $0.104^{\star \star \star}$ & $-0.085^{\star \star \star}$ & $0.029^{\star \star \star}$ & 1.000 \\
\hline Mean & 0.501 & 0.289 & 10.204 & 2.207 & 17.675 & 0.672 & 0.489 \\
\hline Standard deviation & 0.500 & 0.395 & 1.130 & 3.695 & 1.246 & 21.255 & 0.215 \\
\hline
\end{tabular}

${ }^{* * *} p<0.01$.

TABLE 8 | Results of baseline regression.

\begin{tabular}{|c|c|c|c|}
\hline Variables & & (1) & (2) \\
\hline Explanatory variable & $\mathrm{RPI}$ & & $\begin{array}{c}0.149^{\star \star \star} \\
(4.027)\end{array}$ \\
\hline \multirow[t]{17}{*}{ Control variables } & InGDPP & $\begin{array}{c}-0.139^{\star \star \star} \\
(-2.703)\end{array}$ & $\begin{array}{c}-0.140^{* \star} \\
(-2.726)\end{array}$ \\
\hline & RAW & $\begin{array}{c}-0.035^{\star \star \star} \\
(-5.893)\end{array}$ & $\begin{array}{c}-0.033^{\star \star} \\
(-5.649)\end{array}$ \\
\hline & $\ln \llcorner A B$ & $\begin{array}{c}0.043 \\
(0.376)\end{array}$ & $\begin{array}{c}0.060 \\
(0.529)\end{array}$ \\
\hline & $\mathrm{CA}$ & $\begin{array}{c}0.052 \\
(1.164)\end{array}$ & $\begin{array}{c}0.052 \\
(1.180)\end{array}$ \\
\hline & Lnsize & $\begin{array}{c}0.051^{\star \star \star} \\
(2.907)\end{array}$ & $\begin{array}{c}0.052^{\star \star \star} \\
(2.927)\end{array}$ \\
\hline & $\mathrm{ROA}$ & $\begin{array}{c}-0.121 \\
(-1.141)\end{array}$ & $\begin{array}{c}-0.121 \\
(-1.141)\end{array}$ \\
\hline & Lnpatent & $\begin{array}{l}-0.012 \\
(-0.636)\end{array}$ & $\begin{array}{c}-0.008 \\
(-0.450)\end{array}$ \\
\hline & Growth & $\begin{array}{c}0.004 \\
(1.571)\end{array}$ & $\begin{array}{c}0.004 \\
(1.564)\end{array}$ \\
\hline & Lev & $\begin{array}{l}-0.127^{\star} \\
(-1.949)\end{array}$ & $\begin{array}{l}-0.124^{*} \\
(-1.904)\end{array}$ \\
\hline & alab & $\begin{array}{l}0.000^{\star \star} \\
(2.164)\end{array}$ & $\begin{array}{l}0.000^{\star *} \\
(2.133)\end{array}$ \\
\hline & Foreign & $\begin{array}{l}-0.040^{\star \star} \\
(-2.100)\end{array}$ & $\begin{array}{l}-0.040^{\star \star} \\
(-2.100)\end{array}$ \\
\hline & Cont & $\begin{array}{c}0.059 \\
(1.134)\end{array}$ & $\begin{array}{c}0.055 \\
(1.047)\end{array}$ \\
\hline & Share & $\begin{array}{c}0.003^{\star \star *} \\
(2.753)\end{array}$ & $\begin{array}{c}0.003^{\star \star \star} \\
(2.804)\end{array}$ \\
\hline & _cons & $\begin{array}{c}-0.696 \\
(-0.287)\end{array}$ & $\begin{array}{c}-1.092 \\
(-0.451)\end{array}$ \\
\hline & $N$ & 8,032 & 8,032 \\
\hline & $R^{2}$ & 0.639 & 0.640 \\
\hline & $\mathrm{F}$ & 5.829 & 6.583 \\
\hline
\end{tabular}

${ }^{*} \mathrm{p}<0.1$

${ }^{* *} \mathrm{p}<0.05$.

${ }^{* * *} p<0.01$.

coefficient of RPI is 0.149 , which is significant at the level of $1 \%$, indicating that the host country's environmental regulation promotes the enterprises' MIRP, thus proving that Hypothesis 1 holds.

\section{Moderating Effect Analysis}

Table 9 shows the empirical results of Model 2, thus analyzing the moderating effect of green technology innovation. The regression
TABLE 9 | Results of moderating variables regression.

\begin{tabular}{|c|c|c|c|}
\hline Variables & & (1) & (2) \\
\hline \multirow[t]{3}{*}{ Explanatory variables } & $\mathrm{RPI}$ & $\begin{array}{c}0.140^{\star \star \star} \\
(3.760)\end{array}$ & $\begin{array}{c}0.165^{\star \star \star} \\
(4.318)\end{array}$ \\
\hline & RPI*Gpatents & $\begin{array}{l}0.001^{\star *} \\
(2.312)\end{array}$ & \\
\hline & $\mathrm{RPI}{ }^{\star} \mathrm{CSR}$ & & $\begin{array}{l}-0.001^{*} \\
(-1.685)\end{array}$ \\
\hline \multirow[t]{17}{*}{ Control variables } & InGDPP & $\begin{array}{c}-0.141^{\text {***}} \\
(-2.753)\end{array}$ & $\begin{array}{c}-0.138^{\star \star \star} \\
(-2.679)\end{array}$ \\
\hline & RAW & $\begin{array}{c}-0.033^{\star \star \star} \\
(-5.608)\end{array}$ & $\begin{array}{c}-0.034^{\star \star \star} \\
(-5.725)\end{array}$ \\
\hline & $\ln \llcorner A B$ & $\begin{array}{c}0.056 \\
(0.495)\end{array}$ & $\begin{array}{c}0.063 \\
(0.550)\end{array}$ \\
\hline & CA & $\begin{array}{c}0.054 \\
(1.214)\end{array}$ & $\begin{array}{c}0.054 \\
(1.217)\end{array}$ \\
\hline & Lnsize & $\begin{array}{c}0.051^{\star \star \star} \\
(2.879)\end{array}$ & $\begin{array}{c}0.052^{\star \star \star \star} \\
(2.953)\end{array}$ \\
\hline & $\mathrm{ROA}$ & $\begin{array}{c}-0.121 \\
(-1.146)\end{array}$ & $\begin{array}{c}-0.113 \\
(-1.068)\end{array}$ \\
\hline & Lnpatent & $\begin{array}{c}-0.009 \\
(-0.464)\end{array}$ & $\begin{array}{c}-0.008 \\
(-0.431)\end{array}$ \\
\hline & Growth & $\begin{array}{c}0.004 \\
(1.582)\end{array}$ & $\begin{array}{c}0.003 \\
(1.511)\end{array}$ \\
\hline & Lev & $\begin{array}{l}-0.123^{\star} \\
(-1.879)\end{array}$ & $\begin{array}{l}-0.121^{*} \\
(-1.849)\end{array}$ \\
\hline & alab & $\begin{array}{l}0.000^{* \star} \\
(2.094)\end{array}$ & $\begin{array}{l}0.000^{\star *} \\
(2.153)\end{array}$ \\
\hline & Foreign & $\begin{array}{l}-0.037^{\star \star} \\
(-1.976)\end{array}$ & $\begin{array}{l}-0.040^{\star *} \\
(-2.118)\end{array}$ \\
\hline & Cont & $\begin{array}{c}0.057 \\
(1.088)\end{array}$ & $\begin{array}{c}0.057 \\
(1.091)\end{array}$ \\
\hline & Share & $\begin{array}{c}0.003^{\star \star \star} \\
(2.826)\end{array}$ & $\begin{array}{c}0.003^{\star \star \star} \\
(2.790)\end{array}$ \\
\hline & _cons & $\begin{array}{l}-1.015 \\
(-0.419)\end{array}$ & $\begin{array}{c}-1.201 \\
(-0.496)\end{array}$ \\
\hline & $N$ & 8,032 & 8,032 \\
\hline & $R^{2}$ & 0.640 & 0.640 \\
\hline & $\mathrm{F}$ & 6.505 & 6.335 \\
\hline
\end{tabular}

${ }^{*} \mathrm{p}<0.1$.

${ }^{* *} p<0.05$.

${ }^{* * *} \mathrm{p}<0.01$

coefficient of the cross multiplicative term between RPI and Gpatents is 0.001 in column (1), which is significantly positive at the $5 \%$ level, indicating that the green technology innovation has a significant positive moderating effect between host 
TABLE 10 | Sample regression results of different industries.

\begin{tabular}{|c|c|c|c|c|c|c|}
\hline \multirow[t]{2}{*}{ Variables } & \multicolumn{3}{|c|}{ Pollution-intensive enterprises } & \multicolumn{3}{|c|}{ Non-pollution-intensive enterprises } \\
\hline & (1) & (2) & (3) & (4) & (5) & (6) \\
\hline $\mathrm{RPI}$ & $\begin{array}{c}0.149^{\star \star *} \\
(3.817)\end{array}$ & $\begin{array}{c}0.140^{\star \star \star} \\
(3.560)\end{array}$ & $\begin{array}{c}0.171^{\star \star \star} \\
(4.240)\end{array}$ & $\begin{array}{c}-0.060 \\
(-0.520)\end{array}$ & $\begin{array}{c}-0.060 \\
(-0.520)\end{array}$ & $\begin{array}{c}-0.133 \\
(-1.075)\end{array}$ \\
\hline RPI*Gpatents & & $\begin{array}{l}0.001^{\star \star} \\
(2.194)\end{array}$ & & & $\begin{array}{c}-0.000 \\
(-0.039)\end{array}$ & \\
\hline $\mathrm{RPI}{ }^{\star} \mathrm{CSR}$ & & & $\begin{array}{l}-0.001^{\star *} \\
(-2.265)\end{array}$ & & & $\begin{array}{c}0.003 \\
(1.661)\end{array}$ \\
\hline Control Variables & Control & Control & Control & Control & Control & Control \\
\hline Industry, Year & Control & Control & Control & Control & Control & Control \\
\hline$N$ & 6,684 & 6,684 & 6,684 & 1,348 & 1,348 & 1,348 \\
\hline$R^{2}$ & 0.655 & 0.655 & 0.655 & 0.755 & 0.755 & 0.756 \\
\hline $\mathrm{F}$ & 6.630 & 6.513 & 6.534 & 1.063 & 0.991 & 1.178 \\
\hline
\end{tabular}

country's environmental regulation and enterprises' MIRP, thus proving that Hypothesis 2 holds.

Table 9 further shows the empirical results of Model 3, analyzing the moderating effect of corporate social responsibility. The regression coefficient of the cross multiplicative term between CSR and RPI in column (2) is -0.001 , which is significantly negative at the $10 \%$ level, indicating that CSR has a significant negative moderating effect between host country's environmental regulation and enterprises' MIRP, thus proving that Hypothesis 3 holds.

\section{HETEROGENEITY TESTS}

\section{Analysis From the Perspective of Different Industries}

Pollution-intensive industries refer to industries that directly or indirectly produce a large number of pollutants if they are not regulated and treated in the production process. These pollutants will adversely affect human beings, animals and plants, or the ecological environment, and even bring disaster. There is no uniform definition and classification of pollution-intensive industries in academic circles. Tobey (1990) defined the industries whose pollution control accounts for more than $1.85 \%$ of the total cost of enterprises as pollution-intensive industries. Therefore, he classified five industries as pollutionintensive industries: extractive industry, steel industry, paper industry, chemical industry, and primary non-ferrous metals. Youfu Xia (1999) classified industries according to the actual impact of pollutants produced by these industries on the environment. The National Bureau of Statistics divides China's industries into 19 categories to count the industrial distribution of China's foreign direct investment. According to the above classification of polluting industries, among these 19 industries, mining, manufacturing, electricity, gas, and water production and supply are pollution-intensive industries. In order to explore whether there is any difference between the relation of host country's environmental regulation and the enterprises' MIRP in different industries, this paper further divides the samples into pollution-intensive industries and non-pollution-intensive industries according to different industries, and retest Models 1-3. The results are shown in Table 10.

As shown in Table 10, the regression coefficient for pollutionintensive enterprises in column (1) is 0.149 , which is significantly positive at the $1 \%$ level, indicating that for pollution-intensive enterprises, host country's environmental regulation can promote enterprises' MIRP, while the results in column (4) show that the regression coefficient for non-pollution-intensive enterprises is not significant, indicating that for these enterprises, there is no significant relationship between host country' environmental regulation and enterprises' MIRP. The results in column (2) show that in pollution-intensive enterprises, the cross multiplicative term of RPI and Gpatents is significantly positive, indicating that green technology innovation positively moderates the relationship in these enterprises, while it is not significant and green technology innovation does not significantly moderate the relationship in the non-pollutionintensive enterprises. Meanwhile, columns (3) and (6) show that the cross multiplicative term between RPI and CSR in pollution-intensive enterprises is significantly negative, while it is not significant in non-pollution-intensive enterprises. Therefore, different from the sample of pollution-intensive, non-pollution-intensive enterprises' CSR has no significant moderating effect on the relationship between host country's environmental regulation and enterprises' MIRP.

\section{Analysis From the Perspective of Different Property Rights}

In China, state-owned enterprises are the main body of overseas investment enterprises at first. However, with China's entry into the World Trade Organization (WTO), the proportion of stateowned enterprises has dropped from $50 \%$ before China's entry into WTO to about $10 \%$. In contrast, the proportion of overseas investment by non-state-owned enterprises has increased year by year, and non-state-owned enterprises have become the largest subject of overseas investment in China at present. Considering 
TABLE 11 | Sample regression results of different property rights.

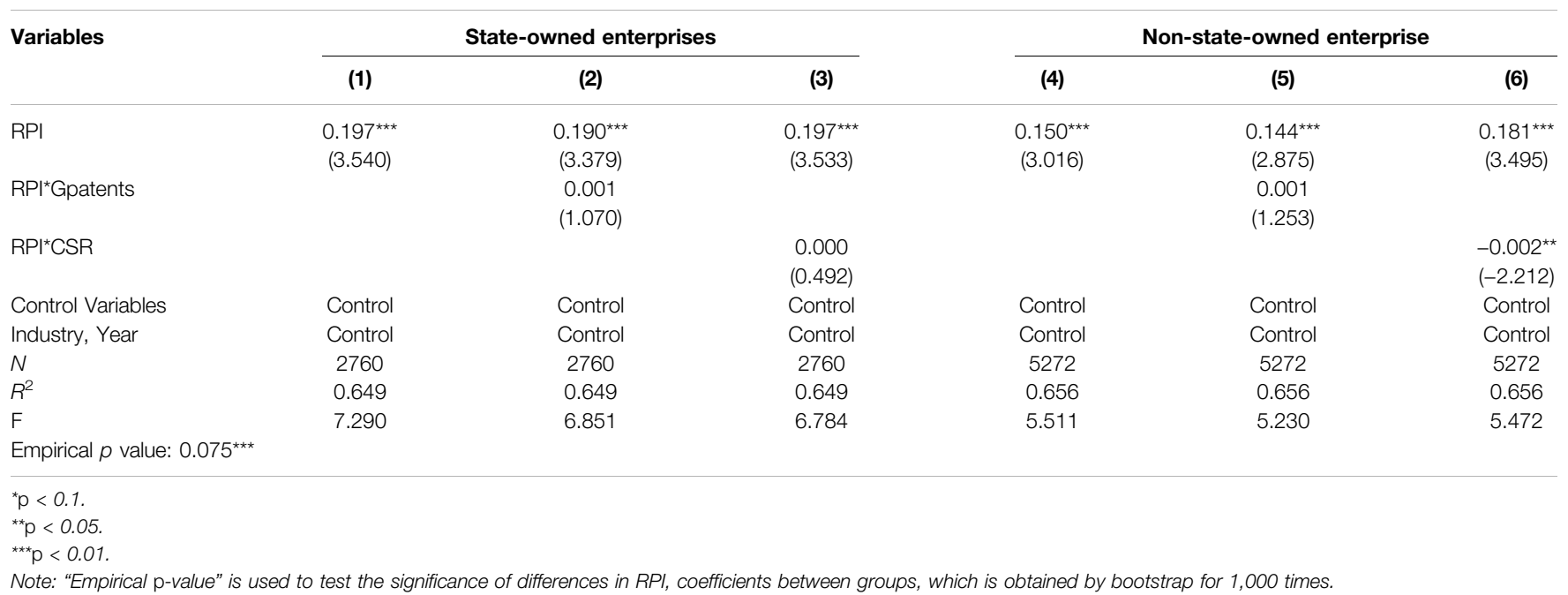

that the internal and external governance mechanisms of different property rights enterprises are different, and the external environment they are facing is also different, different property rights enterprises will have different attitudes towards risks. Therefore, enterprises with different property rights will have different decision-making behaviors and different risk preference when facing environmental regulation. This paper further subdivides the sample into state- and non-state-owned enterprises and re-examines the above models, so as to analyze the influence of host country's environmental regulation and enterprises' MIRP under different property rights backgrounds.

According to the regression results in Table 11, for both stateand non-state-owned enterprises, the regression coefficients of RPI are significantly positive at the $1 \%$ level, indicating that the host country's environmental regulation can promote enterprises' MIRP. Furthermore, the difference in RPI coefficient between these two kinds of enterprises is investigated by bootstrap method, and the empirical $p$-value is -0.075 , which is significant at the level of $1 \%$, indicating that the environmental regulation of host country has a stronger role in promoting the state-owned enterprises' MIRP. Meanwhile, the coefficients of the cross multiplicative term coefficients of RPI and Gpatents in columns (2) and (5) are both not significant, indicating that green technology innovation has no significant moderating effect for these two kinds of enterprises. Comparing columns (3) and (6), corporate social responsibility has a negative moderating effect on the relationship between host country's environmental regulation and non-state-owned enterprises' MIRP, while it is not significant in state-owned enterprises.

\section{Analysis From the Perspective of Different Life Cycle Stages}

According to the theory of enterprise life cycle, the scale, profitability, investment strategy, and innovation willingness of enterprises are obviously different in different development stages (Adizes, 1988). Therefore, it can be reasonably expected that the impact of environmental regulation on the enterprises' MIRP will vary with life cycle of enterprises. Based on the practice of Chang et al. (2020), this paper defines life cycle stages of enterprises with different combinations of operating cash flow, investment cash flow, and financing cash flow. Lastly, this paper divides the enterprise life cycle into three stages: growth, maturity, and recession.

According to Table 12, in the growth stage, the regression coefficient of RPI is 0.220 , and it is significant at the level of $1 \%$. In the maturity stage, the regression coefficient of RPI is 0.233 and significant at the level of $1 \%$. Furthermore, the bootstrap method was used to investigate the difference in RPI coefficient between these two groups. The empirical $p$-value is 0.036 , which is significant at the level of $5 \%$, indicating that the host country's environmental regulation has a stronger role in promoting the enterprises' MIRP in the maturity stage. During the recession stage, the regression coefficient of RPI is 0.126 but not significant. The above results show that the host country's environmental regulation can promote the enterprises' MIRP, but this effect is not significant for enterprises in recession. The moderating role of green technology innovation and social responsibility in the growth and maturity stages of enterprises should be further tested ${ }^{1}$. According to the results in columns (2) and (3), in the growth stage, the cross multiplicative term of environmental regulation and green technology innovation is 0.002 and significant at the level of $1 \%$, while the cross multiplicative term of environmental regulation and social responsibility is not significant. According to the results in columns (5) and (6), in the maturity stage, the cross multiplicative term of environmental regulation and green technology innovation is 0.004 , and the cross multiplicative term of environmental

${ }^{1}$ Because the environmental regulation of the host country has no significant influence on MIRP of enterprises in the recession stage, this paper omits the discussion on the moderating role of green technology innovation and social responsibility on enterprises in this stage. 
TABLE 12 | Sample regression results of different life cycle stages.

\begin{tabular}{|c|c|c|c|c|c|c|c|c|c|}
\hline \multirow[t]{2}{*}{ Variables } & \multicolumn{3}{|c|}{ Growth stage } & \multicolumn{3}{|c|}{ Maturity stage } & \multicolumn{3}{|c|}{ Recession stage } \\
\hline & (1) & (2) & (3) & (4) & (5) & (6) & (7) & (8) & (9) \\
\hline $\mathrm{RPI}$ & $\begin{array}{c}0.220^{\star \star \star} \\
(4.194)\end{array}$ & $\begin{array}{c}0.266^{\star \star \star} \\
(4.750)\end{array}$ & $\begin{array}{c}0.147^{\star \star \star} \\
(2.726)\end{array}$ & $\begin{array}{c}0.233^{\star \star \star} \\
(3.516)\end{array}$ & $\begin{array}{c}0.200^{\star \star \star} \\
(3.001)\end{array}$ & $\begin{array}{c}0.228^{\star \star \star} \\
(3.324)\end{array}$ & $\begin{array}{c}0.126 \\
(1.040)\end{array}$ & $\begin{array}{c}0.089 \\
(0.715)\end{array}$ & $\begin{array}{c}0.119 \\
(0.895)\end{array}$ \\
\hline $\mathrm{RPI}{ }^{\star}$ Gpatents & & $\begin{array}{l}0.002^{\star \star} \\
(2.444)\end{array}$ & & & $\begin{array}{c}0.004^{\star \star \star} \\
(3.511)\end{array}$ & & & $\begin{array}{c}0.006 \\
(1.431)\end{array}$ & \\
\hline $\mathrm{RPI}{ }^{\star} \mathrm{CSR}$ & & & $\begin{array}{c}-0.001 \\
(-0.512)\end{array}$ & & & $\begin{array}{c}-0.004^{\star \star \star} \\
(-5.475)\end{array}$ & & & $\begin{array}{c}0.000 \\
(0.128)\end{array}$ \\
\hline Control Variables & Control & Control & Control & Control & Control & Control & Control & Control & Control \\
\hline Industry, Year & Control & Control & Control & Control & Control & Control & Control & Control & Control \\
\hline$N$ & 4274 & 4274 & 4274 & 2772 & 2772 & 2772 & 986 & 986 & 986 \\
\hline$R^{2}$ & 0.582 & 0.583 & 0.586 & 0.605 & 0.607 & 0.605 & 0.715 & 0.716 & 0.715 \\
\hline $\mathrm{F}$ & 86.908 & 81.627 & 83.783 & 51.660 & 49.292 & 48.217 & 22.988 & 21.627 & 21.425 \\
\hline Empirical $p$-value: & & & & & & & & & \\
\hline
\end{tabular}

regulation and social responsibility is -0.004 , which are both significant at the level of $1 \%$. The results show that green technology innovation will positively moderate the influence of host country's environmental regulation on enterprises' MIRP in both growth and maturity stages, while social responsibility only plays a negative role in matured enterprises.

\section{Analysis From the Perspective of Different Country Types}

In 2013, China put forward a major initiative of "the Belt and Road." In order to strengthen ecological protection along "the Belt and Road," the Chinese government has promulgated the 13th Five-Year Plan for Ecological Protection, the Guidance on Promoting Green Belt and Road Construction, and "the Belt and Road" Ecological Environmental Protection Cooperation Plan was promulgated to regulate the environmental behavior of Chinese enterprises in the Belt and Road countries. Then, whether "the Belt and Road" countries and non-"the Belt and Road" countries have different effects on the relationship between environmental regulation and enterprises' MIRP is examined. This paper further divides the samples into two subsamples according to whether it is a "the Belt and Road" country so as to answer this question. The regression results are shown in Table $\mathbf{1 3}$.

According to Table 13, the results in columns (1) and (4) show that the coefficients of RPI are 0.123 and 0.300 , and both are significantly positive at $1 \%$ level, indicating that the "sanctuary effect" exists in both "the Belt and Road" countries and non-"the Belt and Road" countries. Furthermore, the differences in RPI coefficients in these two kinds of countries are investigated by bootstrap method. The empirical $p$-value is 0.021 and significant at the level of $1 \%$, indicating that environmental regulation in non-"the Belt and Road" countries have a more significant impact on enterprises' MIRP. The results in columns (6) show that when non "the Belt and Road" countries are the host countries, corporate social responsibility plays a negative role in moderating the relationship between environmental regulation and enterprises' MIRP, while for "the Belt and Road" countries, the moderating effects of green technology innovation and social responsibility are not significant.

\section{ROBUSTNESS TESTS}

In this paper, "carbon dioxide emissions per unit GDP" is used to replace environmental regulation intensity for robustness test. "Carbon emissions per unit GDP," also known as "carbon intensity," refers to the carbon dioxide emissions generated by each unit growth of GDP. "Carbon dioxide emissions per unit GDP” is related to a country's energy structure, energy technology level, industrial structure change, urbanization process, and scale. Thus, carbon dioxide emission has become the main policy index of environmental regulation. As early as 1997, Kyoto Protocol stipulated the emission reduction targets of greenhouse gases including carbon dioxide in various countries. In this paper, the average value of indicators from 2010 to 2018 is calculated, and the data come from the World Bank. The "Environmental Regulation Intensity (RPI)" used in this paper is a comprehensive indicator of environmental regulation, and it is a comprehensive evaluation of policy making, policy implementation, and policy effect of environmental regulation. "Carbon dioxide emissions per unit GDP $\left(\mathrm{CO}_{2} / \mathrm{GDP}\right)$ " is a response to the effect of environmental regulation and an indirect indicator to measure the intensity of environmental regulation. The lower the carbon intensity, the fewer the greenhouse gas emission per unit output, and the cleaner the production, the stricter the environmental regulation. The regression results are shown in Table 14; the regression coefficient of $\mathrm{CO}_{2} / \mathrm{GDP}$ is significantly negative in column (1), indicating that the smaller the carbon intensity and the stricter the environmental regulation, the more it can promote MIRP, indicating that the conclusions drawn in this study are robust.

We also used the sub-risk indices of the host countries, i.e., economic risk index (ER), financial risk index (FR), and 
TABLE 13 | Sample regression results of different country types.

\begin{tabular}{|c|c|c|c|c|c|c|}
\hline \multirow[t]{2}{*}{ Variables } & \multicolumn{3}{|c|}{ "The belt and road" countries } & \multicolumn{3}{|c|}{ Non- "the belt and road" countries } \\
\hline & (1) & (2) & (3) & (4) & (5) & (6) \\
\hline $\mathrm{RPI}$ & $\begin{array}{l}0.132^{\star \star \star} \\
(3.920)\end{array}$ & $\begin{array}{l}0.132^{\star \star \star} \\
(3.904)\end{array}$ & $\begin{array}{l}0.127^{\star \star \star} \\
(3.553)\end{array}$ & $\begin{array}{l}0.300^{\star \star \star} \\
(4.823)\end{array}$ & $\begin{array}{l}0.292^{\star \star \star} \\
(4.666)\end{array}$ & $\begin{array}{c}0.320^{\star \star \star} \\
(5.060)\end{array}$ \\
\hline RPI*Gpatents & & $\begin{array}{l}-0.000 \\
(-0.053)\end{array}$ & & & $\begin{array}{c}0.001 \\
(0.890)\end{array}$ & \\
\hline $\mathrm{RPI}{ }^{\star} \mathrm{CSR}$ & & & $\begin{array}{c}0.000 \\
(0.485)\end{array}$ & & & $\begin{array}{l}-0.001^{\star} \\
(-1.737)\end{array}$ \\
\hline Control Variables & Control & Control & Control & Control & Control & Control \\
\hline Industry, Year & Control & Control & Control & Control & Control & Control \\
\hline$N$ & 1,467 & 1,467 & 1,467 & 6,565 & 6,565 & 6,565 \\
\hline$R^{2}$ & 0.771 & 0.771 & 0.771 & 0.580 & 0.580 & 0.580 \\
\hline $\begin{array}{l}\mathrm{F} \\
\text { Empirical } p \text {-value: }\end{array}$ & 1.952 & 1.820 & 1.836 & 14.712 & 13.783 & 13.937 \\
\hline
\end{tabular}

\begin{tabular}{|c|c|c|c|c|}
\hline Variables & (1) & (2) & (3) & (4) \\
\hline $\mathrm{CO}_{2} / \mathrm{GDP}$ & $\begin{array}{c}-1.364^{\star \star \star} \\
(-3.028)\end{array}$ & & & \\
\hline RPI & & $\begin{array}{c}0.056^{\star} \\
(1.741)\end{array}$ & $\begin{array}{c}0.030 \\
(0.921)\end{array}$ & $\begin{array}{l}0.054^{*} \\
(1.681)\end{array}$ \\
\hline Control Variables & Control & Control & Control & Control \\
\hline Industry, Year & Control & Control & Control & Control \\
\hline$N$ & 8,032 & 8,032 & 8,032 & 8,032 \\
\hline$R^{2}$ & 0.639 & 0.727 & 0.719 & 0.726 \\
\hline $\mathrm{F}$ & 6.074 & 10.111 & 10.518 & 9.906 \\
\hline
\end{tabular}

political risk index (PR), as a proxy for MIRP for robustness testing. The regression results are shown in columns (2), (3) and (4) in Table 14. The regression coefficients of economic and political risks showed in columns (2) and (4), respectively, are significantly positive, indicating that host country's environmental regulation promote the political and economic risk preferences of enterprises' multinational investment, although the regression coefficient of financial risk in column (3) is not significant, it still shows that overall it indicates that host country's environmental regulation promote the MIRP, thus proving the conclusion this study is robust.

\section{DISCUSSION}

Many countries achieve the goal of protecting the environment by implementing strict environmental regulation policies. However, there is little research on the impact of the host country's environmental regulation on the enterprises' MIRP. From a practical perspective, it is of great significance for enterprises to comply with the environmental regulation of the host country in the process of multinational investment and to reduce the risks they face in the host country. From a theoretical perspective, the mixed findings can reflect what scholars have long proposed, namely, that there is a "pollution refuge effect" in multinational investment of enterprises in developing countries, and external factors such as institutions will affect enterprises' MIRP. Our study further researches the influencing mechanism by arguing that a country's environmental regulation is very important to the enterprises' MIRP. Specifically, we assume that the host country's environmental regulation will promote the enterprises' MIRP (Hypothesis 1), and the promotion effect will be more obvious in enterprises with stronger green technology innovation capability (Hypothesis 2) and less social responsibility performance (Hypothesis 3). Our empirical results also support these arguments.

In the further research, from the perspective of heterogeneity between enterprises and countries, more valuable findings are drawn, which can be further discussed.

First, for enterprises in different industries, there are differences in the impact of the host country's environmental regulation on enterprises' MIRP. Specifically, the pollutionintensive enterprises will promote the MIRP in the face of the strict environmental regulation of the host country, while the non-pollution-intensive enterprises have no significant influence. Moreover, the moderating roles of green technology innovation and social responsibility are more significant in pollutionintensive enterprises. The possible explanation for the above results is that the environmental costs of pollution-intensive enterprises usually account for a relatively large proportion in production. Therefore, in order to avoid high environmental compliance costs, pollution-intensive enterprises tend to look for countries and regions with loose environmental regulation but unstable political and economic development, thus promoting the MIRP of pollution-intensive enterprises. For pollutionintensive enterprises, stronger green technology innovation ability will enhance their production efficiency and increase their adaptability and risk tolerance to high-risk countries. The stronger the corporate social responsibility, the higher the 
technical standards, so as to adapt to the strict environmental laws and regulations, instead of transferring the investment to the host country with loose environmental laws and regulations. For non-pollution-intensive enterprises, their motivation of developing green innovation is insufficient, and the relationship between social responsibility and environmental regulation is also not significant, so its moderating role is not significant. Therefore, the moderating role of green technology innovation and social responsibility commitment is more significant in pollution-intensive enterprises.

Second, for enterprises with different property rights. Although the host country's environmental regulation would significantly promote MIRP of both state-owned and nonstate-owned enterprises, this effect is much stronger in stateowned enterprises. The important strategic position of stateowned enterprises and their connection with the government make it easy for state-owned enterprises to obtain government policy support and financial support (Li and Zheng, 2016). Compared with non-state-owned enterprises, state-owned enterprises have stronger financial strength and technical strength, so they have stronger ability to resist risks. Therefore, state-owned enterprises have stronger risk preference in multinational investment. In addition, the negative moderating effect of social responsibility on environmental regulation on enterprises' MIRP is stronger in non-state-owned enterprises. The reason for this phenomenon may be that social responsibility engagement not only essentially requires enterprises to increase investment in countries with high environmental requirements but also can improve corporate financing constraints and reduce corporate financing costs, thus partially alleviating the cost pressure of environmental compliance when they invest in countries with high environmental requirements. However, due to the relatively low financing constraints and financing costs of state-owned enterprises, there is little room for them to relieve the cost pressure of environmental compliance by social responsibility engagement, thus failing to provide stronger driving force for enterprises to invest in countries with high environmental requirements. Therefore, the social responsibility of stateowned enterprises does not show a stronger negative moderating role.

Third, for enterprises in different life cycle stages, the host country's environmental regulation has a significant role in promoting MIRP of enterprises in growth and maturity stages but has no significant effect on enterprises in recession. Furthermore, it is found that, compared with enterprises in growth stage, the host country's environmental regulation has a stronger role in promoting MIRP of mature enterprises. The possible explanation is that, although environmental regulation will promote the transfer of multinational investment of enterprises in growth, the internationalization experience and technical strength of enterprises are not enough to make them cope with excessive external risks. On the contrary, because of stronger capital and technical strengths, enterprises in mature stage have stronger capability in resisting the risks of the host country. Therefore, when mature enterprises are faced with strict host country's regulation, they have higher motivation to shift their investment to countries with low environmental requirements but high risks. Different from the previous two stages, enterprises in recession have frequent business problems (Cui and Tang, 2015), and "risk minimization" has become their primary business goal. Therefore, it may be difficult for enterprises to respond adequately to the environmental regulation of the host country, thus passivating the policy effectiveness of the host country. Therefore, for enterprises in recession, the environmental regulation of the host country will not have a significant impact on the risk preference of enterprises' multinational investment. In addition, the previous results show that the negative moderating effect of social responsibility only exists in mature enterprises, but this moderating effect is not significant in growing enterprises. This result shows that mature enterprises pay more attention to environmental protection and social benefits, and the commitment of social benefits will restrain the impulse of enterprises to transfer multinational investment due to environmental regulation.

Fourth, for different types of host countries, although the environmental regulation of "the Belt and Road" countries and non-"the Belt and Road" countries have a significant role in promoting enterprises' MIRP, the environmental regulation of non-"the Belt and Road" countries have a stronger role in promoting enterprises' MIRP. The possible explanation is that compared with investing in "the Belt and Road" countries, enterprises' investing in non-"the Belt and Road" countries will be granted with less government policy support and financial subsidies, so the strengthening of environmental regulation will lead to stronger willingness of enterprises to flee from non-"the Belt and Road" countries. In addition, the negative moderation effect of social responsibility is not significant in "the Belt and Road" countries, which may be because enterprises' investment in "the Belt and Road" countries usually implies some strategic objectives except for economic purposes, so social responsibility will not inhibit the promotion of environmental regulation on enterprises' risk preference in multinational investment.

\section{CONCLUSION}

Based on the "Pollution Shelter" Hypothesis and Porter Hypothesis, this study takes Chinese enterprises in Shanghai and Shenzhen A-shares from 2010 to 2019 as research samples and empirically studies the relationship between the host country's environmental regulation and enterprises' MIRP, and the moderating effect of green technology innovation and social responsibility. The empirical results show that the host country's environmental regulation can promote enterprises' MIRP, and the green technology innovation has a positive moderating effect, while corporate social responsibility will negatively moderate the relationship between the host country's environmental regulation and enterprises' MIRP. 


\section{Theoretical Implications}

First of all, at present, the literature about multinational investment of enterprises mostly focuses on the investment level and investment location from the macro- or microperspectives and rarely involves the risk preference of multinational investment of enterprises. This study effectively broadens the perspective of multinational investment of enterprises and promotes the development of multinational investment theory of enterprises. Second, this paper not only constructs the comprehensive risk index of the host country but also innovatively constructs the risk index of multinational investment of enterprises based on this index, which promotes the quantitative research of multinational investment risk of enterprises. Third, this paper studies the host country's environmental regulation and the risk preference of multinational investment in the same framework, which expands the research vision of environmental regulation and enriches the relevant theories of environmental regulation. Finally, from the perspective of green technology innovation and social responsibility, this paper studies the mechanism of the host country's environmental regulation on the risk preference of enterprises' multinational investment and deepens the relevant theory of the formation mechanism of enterprises' multinational investment risk preference.

\section{Practical Implications}

First, this paper studies the risk preference of multinational investment under the background of double cycle, which is helpful to promote high-quality OFDI and high-level openingup of China's economy. Second, this paper discusses the differential impact of host country environmental regulation on enterprises' multinational investment risk preference and the moderating role of enterprises' green technology innovation and social responsibility under different industries, property rights, life cycle stages, and host country types, which helps to deepen enterprises' understanding of multinational investment risk preference and promote the optimization of enterprises' investment decision-making. It can also provide empirical evidence for the government's policy optimization in cross-border investment, green technology innovation, and social responsibility. Third, the research of this paper will help to deepen the understanding of the basic characteristics and basic laws of Chinese enterprises' multinational investment, provide empirical evidence for the improvement of policies in relevant countries, including foreign investment policies and environmental regulation, and also provide beneficial references for countries to deepen economic exchanges with China. Finally, multinational corporations are under the pressure of environmental regulation of the host country, which will affect their risk preference of multinational investment. In this process, due to the flow of all kinds of resources, the enterprise supply chain management strategy will also change accordingly, and more green supply chain management will be carried out (Zhou, 2020), which will eventually have a positive effect on the enterprise environmental performance (Zhang et al., 2019). Therefore, the research conclusion of this paper is conducive to promote enterprises to increase green supply chain management and practice according to the environmental regulation of the host country in the process of multinational investment, so as to improve enterprise environmental performance and achieve the purpose of effective environmental protection.

\section{Policy Suggestions}

This study can provide useful references for business decisionmaking and government policy-making: (1) for enterprises, it is necessary to conduct extensive and in-depth investigation on the host country before investment, comprehensively evaluate its potential risks, and make objective investment decisions. Second, the differentiation strategy of each stage should be formulated according to the industry, life cycle, and the type of investment host country. Third, we should improve the management's awareness of environmental protection and increase green R\&D investment and technology exchange, so as to improve the enterprise's green technology innovation ability and consciously fulfill the responsibility of environmental protection. Finally, due to the problems of long term and high uncertainty in enterprise innovation, it takes a certain time to improve the innovation output and innovation efficiency. Therefore, enterprises should adopt diversified business strategies to reduce the adverse impact of host country risks. (2) For government departments, first, they should collect and release all kinds of information of the host country in time and disclose the political, economic and financial risk information and environmental regulation information of the host country, so as to ensure the wide integrity and timeliness of information dissemination. Second, relevant departments should encourage enterprises and host countries to promote the exchange of environmental protection technologies through economic cooperation, cooperate to tackle major scientific and technological problems, and jointly improve the green innovation efficiency of enterprises. Finally, we also need to correctly guide the green technology innovation behavior of enterprises, encourage enterprises to protect the environment, and fulfill their social responsibility while improving performance.

\section{Limitations and Suggestions for Further Research}

There are still some limitations in this paper. First of all, the research of this paper is based on the sample of Chinese multinational corporations, and the conclusions may not be applicable to other countries. In the future, we can expand the research sample from Chinese multinational investment enterprises to more countries and appropriately extend the sample time span, which will help to obtain more universal conclusions. Second, due to the difficulty of data acquisition, when analyzing the risk of multinational investment in the host country, this paper only considers whether the enterprise invests in the relevant country and does not consider the amount of investment, which is not conducive to considering the risk level of its assets due to multinational investment from a more comprehensive perspective. In the future, we will further strengthen the collection of manual data and use risk-weighted 
assets as the explanatory variable for re-examination, so as to draw some conclusions based on risk assets, which provides an effective supplement to this study. Third, this paper only studies the relationship between the host country's environmental regulation and enterprises' multinational investment risk preference from the perspectives of different industries, ownership, life cycle, and whether it is a "the belt and road" country. Further research can be conducted from other angles in the future, such as whether the enterprise is supported by industrial policies, the resource endowment of the host country, and the institutional distance of the host country, so as to expand the relevant research of this paper. Finally, this paper only considers the political, economic, and financial risks when constructing the risk indicators of the host country. In the future, it can further increase indicators including social risks and cross-

\section{REFERENCES}

Adizes, I. (1988). Corporate Life Cycles: How and Why Corporations Grow and Die and what to Do about it. Long Range Plann. 25 (1), 128. doi:10.1016/00246301(92)90356-7

Belderbos, R., Olffen, W. V., and Zou, J. (2011). Generic and Specific Social Learning Mechanisms in Foreign Entry Location Choice. Strat. Mgmt. J. 32 (12), 1309-1330doi. doi:10.1002/smj.938

Cai, X., Lu, Y., Wu, M., and Yu, L. (2016). Does Environmental Regulation Drive Away Inbound Foreign Direct Investment? Evidence from a Quasi-Natural Experiment in China. J. Dev. Econ. 123, 73-85. doi:10.1016/ j.jdeveco.2016.08.003

Carroll, A. B., and Shabana, K. M. (2010). The Business Case for Corporate Social Responsibility: A Review of Concepts, Research and Practice. Int. J. Manag. Rev. 12 (1), 85-105. doi:10.1111/j.1468-2370.2009.00275.x

Chang, X., Zheng, J., and Li, F. (2020). Local Industrial Policy, Enterprise Life Cycle and Technological Innovation-Heterogeneity, Mechanism Test and Government Incentive Structure Difference. Sankei Rev. 11 (6), 21-38. doi:10.14007/j.cnki.cjpl.2020.06.002

Chung, S. (2014). Environmental Regulation and Foreign Direct Investment: Evidence from South Korea. J. Dev. Econ. 108, 222-236. doi:10.1016/ j.jdeveco.2014.01.003

Cole, M. A., Elliott, R. J. R., and Shimamoto, K. (2005). Why the Grass Is Not Always Greener: The Competing Effects of Environmental Regulations and Factor Intensities on US Specialization. Ecol. Econ. 54, 95-109. doi:10.1016/ j.ecolecon.2004.11.014

Copeland, B. R., and Taylor, M. S. (1995). Trade and the Environment: A Partial Synthesis. Am. J. Agric. Econ. 77, 765-771. doi:10.2307/1243249

Cui, Y., and Tang, W. (2015). The Influence of Life Cycle on R\&D Investment: Based on Innovation-Driven Perspective. J. Cent. Univ. Finance Econ. 9, 46-54.

Dagar, V., Khan, M. K., Usman, R. M., Rehman, A. A., Murshed, M., Tillaguango, B., et al. (2021). Variations in Technical Efficiency of Farmers with Distinct Land Size across Agro-Climatic Zones: Evidence from India. J. Clean. Prod. 315, 128109. doi:10.1016/j.jclepro.2021.128109

Dangelico, R. M., and Pontrandolfo, P. (2013). Being 'Green and Competitive': The Impact of Environmental Actions and Collaborations on Firm Performance. Bus. Strat. Env. 24 (6), 413-430. doi:10.1002/bse.1828

Du, X., Shu, B., Qi, C., and Fei, F. (2020). Does CEO's Social Class Affect OFDI's Political Risk Location Choice? Based on the Micro Data of Chinese Multinational Companies. Operations Manag. 29 (03), 217-228.

El Ghoul, S., Guedhami, O., Kwok, C. C. Y., and Mishra, D. R. (2011). Does Corporate Social Responsibility Affect the Cost of Capital. J. Banking Finance 35, 2388-2406. doi:10.1016/j.jbankfin.2011.02.007

$\mathrm{Fu}$, Jingyan., and Li, Lisha. (2010). FDI, Environmental Regulation and Pollution Refuge Effect: Empirical Analysis Based on Provincial Data in China. J. Public Manag. 3, 65-74. cultural risks, so as to form a more comprehensive risk indicator system and enrich the research conclusions of this paper.

\section{DATA AVAILABILITY STATEMENT}

The original contributions presented in the study are included in the article/supplementary material. Further inquiries can be directed to the corresponding author.

\section{AUTHOR CONTRIBUTIONS}

$\mathrm{CP}$ and $\mathrm{HJ}$ conceived of the idea for this study. CP conducted the statistical analysis. $\mathrm{HJ}$ contributed to the final write-up.

Henisz, W. J., and Delios, A. (2001). Uncertainty, Imitation, and Plant Location: Japanese Multinational Corporations, 1990-1996. Administrative Sci. Q. 46 (3), 443-475. doi:10.2307/3094871

Islam, M. M., Khan, M. K., Tareque, M., Jehan, N., and Dagar, V. (2021). Impact of Globalization, Foreign Direct Investment, and Energy Consumption on CO2 Emissions in Bangladesh: Does Institutional Quality Matter. Environ. Sci. Pollut. Res. 28, 48851-48871. doi:10.1007/s11356-021-13441-4

John, A., and Lawton, T. C. (2018). International Political Risk Management: Perspectives, Approaches and Emerging Agendas. Int. J. Manag. Rev. 20 (4), 847-879. doi:10.1111/ijmr.12166

Kang, Y., and Jiang, F. (2012). FDI Location Choice of Chinese Multinationals in East and Southeast Asia: Traditional Economic Factors and Institutional Perspective. J. World Business 47 (1), 45-53. doi:10.1016/j.jwb.2010.10.019

Khan, M. K., Babar, S. F., Oryani, B., Dagar, V., Rehman, A., Zakari, A., et al. (2021). Role of Financial Development, Environmental-Related Technologies, Research and Development, Energy Intensity, Natural Resource Depletion, and Temperature in Sustainable Environment in Canada. Environ. Sci. Pollut. Res. 28 (32), 43007-43020. doi:10.1007/s11356-021-15421-0

Kraus, S., Rehman, S. U., and García, F. J. S. (2020). Corporate Social Responsibility and Environmental Performance: The Mediating Role of Environmental Strategy and Green Innovation. Technol. Forecast. Soc. Change 160, 120262. doi:10.1016/j.techfore.2020.120262

Li, J., and Yao, F. K. (2010). The Role of Reference Groups in International Investment Decisions by Firms from Emerging Economies. J. Int. Manag. 16 (2), 143-153. doi:10.1016/j.intman.2010.03.005

Li, W., and Zheng, M. (2016). Substantive Innovation or Strategic Innovation?: The Influence of Macro Industrial Policies on Micro Enterprise Innovation. Econ. Res. 51 (04), 60-73.

Li, X. (2020). Research on the Impact of Environmental Regulation on China's Foreign Direct Investment:Based on the Perspective of Home Country. Beijing, China: University of International Business and Economics.

Lin, K. J., Tan, J., Zhao, L., and Karim, K. (2015). In the Name of Charity: Political Connections and Strategic Corporate Social Responsibility in a Transition Economy. J. Corporate Finance 32, 327-346. doi:10.1016/j.jcorpfin.2014.10.007

Lin-Hi, N., and Muller, K. (2013). The CSR Bottom Line: Preventing Corporate Social Irresponsibility. J. Business Res. 66 (10), 1928-1936. doi:10.1016/ j.jbusres.2013.02.015

Mihov, A., and Naranjo, A. (2019). Corporate Internationalization, Subsidiary Locations, and the Cost of Equity Capital. J. Int. Bus Stud. 50 (9), 1544-1565. doi:10.1057/s41267-018-00207-3

Quer, D., Claver, E., and Rienda, L. (2012). Political Risk, Cultural Distance, and Outward Foreign Direct Investment: Empirical Evidence from Large Chinese Firms. Asia Pac. J. Manag. 29 (4), 1089-1104. doi:10.1007/s10490-011-9247-7

Rehman, A., Ma, H., Chishti, M. Z., Ozturk, I., Irfan, M., and Ahmad, M. (2021). Asymmetric Investigation to Track the Effect of Urbanization, Energy Utilization, Fossil Fuel Energy and CO2 Emission on Economic Efficiency in China: Another Outlook. Environ. Sci. Pollut. Res. 28, 17319-17330. doi:10.1007/s11356-020-12186-w 
Shahbaz, M., Nasir, M. A., Hille, E., and Mahalik, M. K. (2020). UK's Net-Zero Carbon Emissions Target: Investigating the Potential Role of Economic Growth, Financial Development, and R\&D Expenditures Based on Historical Data (1870-2017). Technol. Forecast. Soc. Change 161, 120255. doi:10.1016/j.techfore.2020.120255

Sharma, R., Shahbaz, M., Kautish, P., and Vo, X. V. (2021a). Does Energy Consumption Reinforce Environmental Pollution? Evidence from Emerging Asian Economies. J. Environ. Manage. 297, 113272. doi:10.1016/ j.jenvman.2021.113272

Sharma, R., Shahbaz, M., Sinha, A., and Vo, X. V. (2021b). Examining the Temporal Impact of Stock Market Development on Carbon Intensity: Evidence from South Asian Countries. J. Environ. Manage. 297, 113248. doi:10.1016/j.jenvman.2021.113248

Shu, B., and Du, X. (2020). CEO's Cognitive Heterogeneity in Management and OFDI's Political Risk Location Preference of Multinational Companies:Based on Micro Data of Chinese Multinational Companies. J. Northeast. Univ. (Natural Sci. Edition) 5, 753-760.

Sinha, A., and Shahbaz, M. (2018). Estimation of Environmental Kuznets Curve for CO2 Emission: Role of Renewable Energy Generation in India. Renew. Energ. 119, 703-711. doi:10.1016/j.renene.2017.12.058

Tang, J. (2015). Testing the Pollution Haven Effect: Does the Type of FDI Matter. Environ. Resource Econ. 60, 549-578. doi:10.1007/s10640-014-9779-7

Tobey, J. A. (1990). The Effects of Domestic Environmental Policies on Patterns of World Trade: An Empirical Test. Kyklos 43 (43), 191-209. doi:10.1111/j.14676435.1990.tb00207.x

Tong, J., Liu, W., and Xue, J. (2016). Environmental Regulation, Factor Input Structure and Industrial Transformation and Upgrading. Econ. Res. 7, 43-57.

Wang, M., Zhang, H., Li, Y., and Wang, Z. (2021). Study on the Dual Heterogeneity of the Transmission Path of Green Technology Innovation Performance: Based on the Survey Data of 642 Industrial Enterprises. Sci. Sci. Tech. Manag. 42 (08), 141-166.

Weng, H.-H., Chen, J.-S., and Chen, P.-C. (2015). Effects of Green Innovation on Environmental and Corporate Performance: A Stakeholder Perspective. Sustainability 7 (5), 4997-5026. doi:10.3390/su7054997

Wu, J., and Zheng, Q. (2020). The Host Country's Environmental Regulation and the Motivation of China's Foreign Direct Investment-Empirical Evidence from Countries along the Belt and Road Initiative. J. Lanzhou Univ. (Social Sci. Edition) 48 (04), 49-59.

Xia, Y. (1999). A Study on the Current Situation of Foreign Investment in China's Pollution-Intensive Industries, its Consequences and its Countermeasures. Manag. World 3, 109-123.
Yuan, Q., and Chen, G. (2018). Political Risk Analysis of Enterprises' Direct Investment in ASEAN. Int. Business (Journal Univ. Int. Business Economics) 3, 122-136. doi:10.13509/j.cnki.ib.2018.03.011

Zakari, A., Toplak, J., Ibtissem, M., Dagar, V., and Khan, M. K. (2021). Impact of Nigeria's Industrial Sector on Level of Inefficiency for Energy Consumption: Fisher Ideal Index Decomposition Analysis. Heliyon 7, e06952. doi:10.1016/ j.heliyon.2021.e06952

Zhang, J., Zhang, X., and Wang, Q. (2019). Research on the Relationship Among Institutional Pressure, Green Supply Chain Management Practice and Enterprise Performance. Wuhan, China: Journal of wuhan textile University, 24-29.

Zhao, T., and Xiao, X. (2019). The Impact of Corporate Social Responsibility on Financial Constraints: Does the Life Cycle Stage of a Firm Matter. Int. Rev. Econ. Finance 63, 76-93. doi:10.1016/j.iref.2018.08.010

Zhao, Y., Shen, Z., and Liao, R. (2015). Cognition of Environmental Regulation, Sense of Social Responsibility and Location Selection of Enterprises in Agglomeration Areas. Ind. Econ. Res. (Bimonthly) 3, 82-91. doi:10.13269/ j.cnki.ier.2015.03.009

Zheng, D., and Shi, M. (2017). Multiple Environmental Policies and Pollution Haven Hypothesis: Evidence from China's Polluting Industries. J. Clean. Prod. 141, 295-304. doi:10.1016/j.jclepro.2016.09.091

Zhou, L. (2020). Research on the Impact of Green Supply Chain Management on the Environmental Performance of Enterprises-Does the Institutional Environment Tend to Regulate. China's collective economy 35, 17-20.

Conflict of Interest: The authors declare that the research was conducted in the absence of any commercial or financial relationships that could be construed as a potential conflict of interest.

Publisher's Note: All claims expressed in this article are solely those of the authors and do not necessarily represent those of their affiliated organizations, or those of the publisher, the editors, and the reviewers. Any product that may be evaluated in this article, or claim that may be made by its manufacturer, is not guaranteed or endorsed by the publisher.

Copyright (c) 2021 Peng and Jiang. This is an open-access article distributed under the terms of the Creative Commons Attribution License (CC BY). The use, distribution or reproduction in other forums is permitted, provided the original author(s) and the copyright owner(s) are credited and that the original publication in this journal is cited, in accordance with accepted academic practice. No use, distribution or reproduction is permitted which does not comply with these terms. 